\title{
The Influence of the Number of Employees on the Quality Management in Pharmaceutical Production
}

\author{
Jingjing Luo ${ }^{1 *}$, Gordon G. Liu' ${ }^{1 \#, ~ W e i j u n ~ T i a n ~}{ }^{2+}$ \\ ${ }^{1}$ China Pharmaceutical University, Nanjing, China \\ ${ }^{2}$ School of Management, Shanghai University, Shanghai, China \\ Email: luojj_j@163.com, "liugg0815@163.com
}

How to cite this paper: Luo, J.J., Liu, G.G. and Tian, W.J. (2019) The Influence of the Number of Employees on the Quality Management in Pharmaceutical Production. Open Journal of Social Sciences, 7, 64-74. https://doi.org/10.4236/jss.2019.73005

Received: January 29, 2019

Accepted: March 5, 2019

Published: March 8, 2019

Copyright () 2019 by author(s) and Scientific Research Publishing Inc. This work is licensed under the Creative Commons Attribution International License (CC BY 4.0).

http://creativecommons.org/licenses/by/4.0/

Open Access

\begin{abstract}
Based on the survey data from the questionnaire of Quality Management of Pharmaceutical Production Enterprises in Anhui Province, this research examines the relationship between the number of employees and inspection for GMP of pharmaceutical manufacturers by adopting OLS model and Logit model. We find that the more employees there are, the better their inspection results are. Enterprises with large number of employees generally have plenty people to deal with the problems of quality supervision in the production of pharmaceuticals and have a good knowledge of GMP. They can produce high quality medicines. Therefore, small companies should be supervised frequently. In daily supervision, through the number of employees, it can quickly judge the pros and cons of the quality management level of the company, which is beneficial to allocate regulatory resources rationally.
\end{abstract}

\section{Keywords}

Econometrics, Survey, OLS Model, Logit Model, the Number of Employees, Influencing Factor, Pharmaceutical Production

\section{Introduction}

As we all know, medicine is a special commodity, which plays an important role in helping people prevent and treat diseases, regulate physiological functions and improve their health. However, the toxic and side effects caused by inferior and unsafe drugs can also cause injury or even death to humans. Since the twentieth 
century, 12 times of serious drug disasters in human history (Barbara, 2001) [1] have taught us a harsh lesson. In order to ensure the safety of drug quality at the source, it is necessary to strengthen the supervision of drug production process of pharmaceutical enterprises.

Good Manufacturing Practice (GMP) [2] is a key measure to ensure the quality and safety of pharmaceutical production enforced by global regulatory authorities. The implementation of GMP system will fundamentally change the production environment of pharmaceutical enterprises, standardize the order of drug production, and ensure the safety of people's lives. In 2011, the Ministry of Health had released a new version of GMP revised in 2010. In previous qualitative research, it has always been considered that the production quality management of pharmaceuticals is related to six major factors: man, machine, material, method, environment and measurement, but there are several problems in following aspects. First, what characteristics influence on the quality management of pharmaceutical manufacturers? Second, is it possible to identify companies in poor quality management based on these characteristics and increase the frequency of inspection? Figuring out these questions is helpful to reduce regulatory costs.

The human has been considered as the first of the six factors affecting the quality of drug production. Taking the number of employees as the research object and based on the survey data from the questionnaire of Quality Management of Pharmaceutical Production Enterprises in Anhui Province, this research studies the relationship between the number of employees and inspection for GMP of pharmaceutical manufacturers by adopting OLS model and Logit model. And suggestions are put forward for the supervision and development of drug enterprises.

\section{Theoretical Analysis and Research Hypotheses}

Most of the current literature on quality management focuses on identifying and defining quality management structures [3] and clarifying the relationships between these structures [4], as well as conducting multidimensional evaluation of concepts and performance [5]. Enterprise scale is an important characteristic variable reflecting an enterprise's production and operation capacity, which mainly includes the number of employees, total assets and total business.

The research about the influence of the number of employees on the quality management in pharmaceutical production at home and abroad now is mainly carried out in the following aspects. In terms of qualitative research, the relationship between employee and enterprise management is studied from the perspective of human resources management. David E. Guest (2011) explored the importance of human resources in modern enterprise management [6], and optimized the enterprise human resource management model, which is advantageous to the promotion enterprise's comprehensive strength and market competitiveness. Kaifeng Jiang (2012) pointed out that in the process of modernized development of enterprise management, employees should be taken as the man- 
agement subject to carry out education and training of professional knowledge and advanced skills, which can improve enterprise management in an all-round way while ensuring the effective implementation of performance management [7]. Quantitative research can reflect the impact of raw materials, scale of employment and other factors of production on the development of enterprises, as well as the level of enterprise management. This method is convenient for statistical analysis and comparison, and the data is easy to obtain, so it is widely used in empirical research by scholars. At present, the research on enterprise scale is mainly carried out in a quantitative way, which is mainly about the relationship between the number of employees in enterprise and enterprise output variables like enterprise management level, enterprise productivity, research and development efficiency. Jiang Jiyu et al. (2018) found that the size of enterprises was positively correlated with the total factor productivity of agricultural product processing industry by using the data of agricultural product processing industry in Anhui Province [8]. Luo Yingxing et al. (2018) concluded that the larger the scale of China's pharmaceutical enterprises, the higher the degree of industrial agglomeration, and the higher the research and development efficiency [9]. Song Yang (2014) studied the R \& D input of 316 companies listed in GEM (growth enterprise market) from the perspective of enterprise scale, using indicators of number of employees amount of assets and sales revenue, and found no significant correlation between R \& D input and number of employees [10].

Specific to the quality management level research of pharmaceutical production enterprises, the management level is usually evaluated by the result of drug production inspection in the world. While in the ICHQ9 [11] and ICHQ10 [12] released by FDA in 2009, the quality risk of drugs was defined, and at present the risk assessment method is often used to evaluate the level of production management in drug production inspection. The quality management level of drug production enterprises is evaluated by the results of drug production inspection. The representative studies are as following.

The FDA of the United States has established the scoring system [13] for drug manufacturing inspection enterprises, the data tracking system (pharmacovigilance reporting system (FARS), drug quality reporting system (DQRS), and biological product defect reporting system (BPDR)). The system includes receiving, classifying, analyzing and summarizing drug quality reports. What's more, it can digitize drug risk signals, quickly identify major health hazards, and find problems in the inspection of drug, then based on the statistical analysis reports, classifying risks, and adopting different regulatory actions according to the classifications. Besides, FDA divides the influencing factors of enterprise quality management into three categories: product, process and enterprise characteristic risk. John v. Gray et al. (2018) analyzed the factors affecting the product quality of enterprises' overseas factories [14]. T. Ishibashi et al. (2012) studied the relationship between enterprise characteristic variables and the time of drug application [15]. Dai Junhao et al. (2014) studied how to use measurement tools in the process of drug development, production and testing [16]. 
Previous studies have shown that the personnel factor plays a significant role in enterprise quality management and plays an important role in enterprise management level and various performance dimensions. However, the current research methods mostly rely on personal experience and cognitive level, and rarely link corporate characteristics with drug inspection results. Because of the unavailability of inspection data on drug production worldwide (part of the inspection results related to the pharmaceutical process patent technology cannot of enterprises cannot be disclosed in the public media), now there is no research on the correlation between enterprise characteristics and drug production inspection. In this paper, we take the results of GMP inspection as a dependent variable to measure the level of enterprise production quality management. In addition, personnel factor (enterprise scale), which is the most important factor among the six recognized factors of enterprise quality management, is selected to study the relationship between personnel factor and enterprise production quality management level with the tools of econometric model. Compared with previous studies, the contribution of this paper is that OLS model and Logit model are used to study the influence of the number of employees in enterprise characteristic variables on the GMP inspection and evaluation results of drugs, which indirectly measures the quality management in pharmaceutical production. From the perspective of regulators, the situation about unmonitored drug production quality management is got a glimpse from characteristics in enterprises, which provide more convenience for regulators. From the perspective of enterprises, specific development suggestions are given to enterprises and they can improve the quality management level and core competitiveness of drug production.

\section{Data Sources and Descriptive Statistics}

Source: data were obtained from questionnaires on the production quality management of drug manufacturing enterprises in 17 prefectures and cities of Anhui Province.

Survey objects and survey methods: drug manufacturing enterprises in the whole province were classified according to their local conditions and types. For example, according to the type of enterprise in a certain city, it can be divided into sterile drugs, Chinese herbal decoction pieces, non-sterile drugs, medical oxygen and API. The survey objects were selected by stratified random sampling in proportion, and the whole sampling process was carried out on the corresponding sampling software. And the method of self-filling questionnaire and investigator checking has been used. 230 enterprises were selected and distributed for investigation, and 15 invalid questionnaires were removed to form 215 valid questionnaires. In addition, the inspection results (defect items) were matched with the investigated enterprises according to the 2010 GMP certification inspection database of pharmaceutical manufacturing enterprises in Anhui Province. 
Survey content: the questionnaire is composed of two parts, 1) the basic characteristics of the enterprise, including the investigated enterprise, contact person and basic information; 2) questions related to the management of pharmaceutical production, including the characteristic variables of enterprises and the subjective questions answered by enterprises.

Data processing method: Epidata 3.1 was used to establish the questionnaire entry database, and we used double-entry check to ensure the data's accuracy for each valid questionnaire. The data was analyzed by multifactor OLS model and Logit model in STATA 10.

Quality control: many quality control measures have been adopted, such as the design and demonstration of the investigation scheme, the unified training of investigators, the input and verification of pre-investigation data, etc., with clear requirements to ensure the authenticity of data.

\subsection{Econometric Model}

\subsubsection{OLS Regression Model}

For this study, when the quality management level of drug manufacturing enterprises is estimated, the least square method is first used to analyze:

$$
\operatorname{Ln}\left(\frac{P}{1-P}\right)=b_{0}+b_{1} x_{1}+b_{2} x_{2}+\cdots+b_{p} x_{p}+\varepsilon
$$

In Equation (1), $Y$ is the inspection result of the enterprise and it also represents the quality management level of the enterprise. $\beta_{0}$ is the constant term. $i$ represents the coefficient of different influencing factors. $X_{i}$ stands for different influencing factors. $\varepsilon$ is the error term.

\subsubsection{Logit Model}

The dependent variable in this study, namely whether the enterprise passes the GMP inspection, is a typical 0 - 1 discrete selection variable. The binary Logit model can better satisfy the study of the related problems of discrete selection variables, so this model is selected for the study. If the dependent variable does not pass the test, then $Z=1$; if it does, then $Z=0$. It is assumed that the probability of $Z=1$ is $P . x_{i}(i=1,2, \ldots, \mathrm{n})$ is the explanatory variable, various factors affecting production management of drugs. $b_{i}(i=1,2, \ldots, \mathrm{n})$ is the regression coefficient of the $i$-th influencing factor. If $b_{i}$ is positive, it means the $i$ factor has a positive impact on drug production management; if $b_{i}$ is negative, it means it has a negative impact. Logit binary discrete selection model is as follows:

$$
P=F(Z) \frac{1}{1+\mathrm{e}^{-z}}
$$

In formula (1), $Z$ is a linear combination of variables $x_{1}, x_{2}, \ldots, x_{p}$

$$
Z=b_{0}+b_{1} x_{1}+b_{2} x_{2}+\cdots+b_{p} x_{p} ;
$$

By transforming Equations (2) and (3), the Logit model is represented by the occurrence ratio. 


$$
\operatorname{Ln}\left(\frac{P}{1-P}\right)=b_{0}+b_{1} x_{1}+b_{2} x_{2}+\cdots+b_{p} x_{p}+\varepsilon
$$

In Equation (4), $b_{0}$ is a constant term. $b_{i}(i=1,2, \ldots, p)$ is the coefficient of the independent variable. $\varepsilon$ is a random error. The values of $b_{0}$ and $b_{1}$ can be estimated by the maximum likelihood estimation method.

\subsubsection{Variable Setting}

The setting of variables can be divided into two parts: dependent variable and the explanatory variable. The data of the dependent variable part comes from the inspection database of drug manufacturing enterprises of Anhui Provincial assessment and certification center from 2011 to 2016, which is responsible for the inspection of drug manufacturing enterprises in Anhui Province. According to the requirements, the specific information of the enterprise is anonymized. The inspection standard for enterprises is the "drug production quality management standard" (revised in 2010). The inspection results reflect the production quality management level of the enterprise. Inspection results are recorded as defective items, and there are 313 articles in the drug production quality management standard (revised in 2010). If the enterprise fails to comply with a certain provision, the degree of non-compliance shall be classified as general defect, major defect and serious defect according to the risk (frequency of occurrence ${ }^{*}$ possibility of occurrence ${ }^{\star}$ degree of health hazard to the user). According to the classification of inspection results, if there is one serious defect or more than three major defects, the dependent variable will be set to 0 , that is, the production quality management is not good, and the inspection will not pass. If all of them are general defects or major defects below 3 times, it means that the production quality management is ok. After inspection, the dependent variable is set to 1 . According to the nature of the survey data, the explained variables were selected as the quality management of drug production. The quality management of drug production is divided into two levels, "pass the inspection" and "fail the inspection", and the value is " 1 " and " 0 ", which means the quality management is reduced successively.

\subsubsection{Explanatory Variables}

According to the research purpose of this paper, the key explanatory variables in this study are mainly the number of employees in the selected sample. However, it is found from other relevant studies that other characteristic variables such as human, machine, material, method, environment and measurement also play a crucial role in the production quality management of enterprises.

So, in this study, we have the general characteristics variable, risk management characteristics variable, drug eigenvariables, developmental eigenvariables, management system variables, and control the following variables. In terms of the overall characteristics of the enterprise, we control the output value of the enterprise; On the drug eigenvariables, whether a company produces special medicaments is another control variable; Whether the enterprise's R \& D strate- 
gy is innovation is as to control variable of enterprise development. In terms of management system variables, the maintenance cost of the laboratory, the number of SOP of the enterprise and the number of serious deviations of the enterprise are controlled. The values of each factor are shown in Table 1.

Table 1. Definitions and descriptive statistics of variables in this paper.

\begin{tabular}{|c|c|c|c|c|c|c|}
\hline Variable Name & Symbol & Definition & Mean & $\begin{array}{l}\text { Standard } \\
\text { Deviation }\end{array}$ & $\begin{array}{l}\text { Minimum } \\
\text { Value }\end{array}$ & $\begin{array}{l}\text { Maximum } \\
\text { Value }\end{array}$ \\
\hline Special drugs & $\mathrm{x}_{\mathrm{sp}}$ & $\begin{array}{c}\text { The production of special drugs is } 1 \text {, } \\
\text { otherwise it is } 0\end{array}$ & 0.0605 & 0.2389 & 0 & 1 \\
\hline $\begin{array}{l}\text { Logarithm of enterprise } \\
\text { output value }\end{array}$ & $\mathrm{x}_{\mathrm{va}}$ & $\begin{array}{l}\text { Check the logarithm of the annual } \\
\text { output value of the enterprise }\end{array}$ & 6.7780 & 3.3519 & 0 & 11.71368 \\
\hline $\begin{array}{l}\text { Number of } \\
\text { employees }\end{array}$ & $\mathrm{x}_{\mathrm{to}}$ & Number of employees & 33.2326 & 96.9306 & 0 & 1236 \\
\hline $\begin{array}{l}\text { Enterprise development } \\
\text { strategy for innovation }\end{array}$ & $\mathrm{x}_{\mathrm{de}}$ & $\begin{array}{c}\text { Enterprises adopting } \mathrm{r} \& \mathrm{~d} \text { innovation } \\
\text { strategy is } 1 \text {, otherwise it is } 0 .\end{array}$ & 0.3767 & 0.4857 & 0 & 1 \\
\hline $\begin{array}{l}\text { Lab maintenance } \\
\text { cost logarithm }\end{array}$ & $\mathrm{x}_{\text {sys }}$ & Log lab maintenance costs & 2.5396 & 1.2702 & 0 & 6.621406 \\
\hline Number of enterprise sop & $\mathrm{x}_{\text {sop }}$ & Number of sop in the enterprise & 613.9070 & 661.4971 & 1 & 5500 \\
\hline $\begin{array}{c}\text { Number of serious } \\
\text { deviations of enterprises }\end{array}$ & $\mathrm{x}_{\text {main }}$ & $\begin{array}{c}\text { Number of serious } \\
\text { deviations of enterprises }\end{array}$ & 5.0558 & 19.6646 & 0 & 262 \\
\hline $\begin{array}{l}\text { Hardware problems encountered in the } \\
\text { implementation of GMP }\end{array}$ & $\mathrm{x}_{\text {hard }}$ & & & & & \\
\hline $\begin{array}{l}\text { Enterprises never encounter hardware } \\
\text { problems in implementing GMP }\end{array}$ & $\mathrm{x}_{\text {hard1 }}$ & One is yes, and zero is no. & 0.2140 & 0.4111 & 0 & 1 \\
\hline $\begin{array}{l}\text { Enterprises rarely encounter hardware } \\
\text { problems in implementing GMP }\end{array}$ & $\mathrm{x}_{\text {hard} 2}$ & One is yes, and zero is no. & 0.2837 & 0.4519 & 0 & 1 \\
\hline $\begin{array}{l}\text { Enterprises usually encounter hardware } \\
\text { problems in implementing GMP }\end{array}$ & $\mathrm{x}_{\text {hard3 }}$ & One is yes, and zero is no. & 0.3395 & 0.4747 & 0 & 1 \\
\hline $\begin{array}{l}\text { Enterprises often encounter hardware } \\
\text { problems in implementing GMP }\end{array}$ & $\mathrm{x}_{\text {hard4 }}$ & One is yes, and zero is no. & 0.1302 & 0.3373 & 0 & 1 \\
\hline $\begin{array}{l}\text { Enterprises always encounter hardware } \\
\text { problems in implementing GMP }\end{array}$ & $\mathrm{x}_{\text {hard5 }}$ & One is yes, and zero is no. & 0.0326 & 0.1779 & 0 & 1 \\
\hline $\begin{array}{l}\text { Enterprise's understanding } \\
\text { of GMP standard }\end{array}$ & $\mathrm{x}_{\mathrm{un}}$ & & & & & \\
\hline $\begin{array}{l}\text { Enterprises have difficulty } \\
\text { understanding GMP standards }\end{array}$ & $\mathrm{x}_{\mathrm{un} 1}$ & One is yes, and zero is no. & 0.1255 & 0.3321 & 0 & 1 \\
\hline $\begin{array}{l}\text { Enterprises rarely have } \\
\text { difficulty understanding GMP standards }\end{array}$ & $\mathrm{x}_{\mathrm{un} 2}$ & One is yes, and zero is no. & 0.2047 & 0.4044 & 0 & 1 \\
\hline $\begin{array}{l}\text { Enterprises usually have } \\
\text { difficulty understanding GMP standards }\end{array}$ & $\mathrm{x}_{\mathrm{un} 3}$ & One is yes, and zero is no. & 0.3721 & 0.4845 & 0 & 1 \\
\hline $\begin{array}{l}\text { Enterprises often have } \\
\text { difficulty understanding GMP standards }\end{array}$ & $\mathrm{x}_{\mathrm{un} 4}$ & One is yes, and zero is no. & 0.2698 & 0.4449 & 0 & 1 \\
\hline $\begin{array}{l}\text { Enterprises always have } \\
\text { difficulty understanding GMP standards }\end{array}$ & $\mathrm{x}_{\mathrm{un} 5}$ & One is yes, and zero is no. & 0.0279 & 0.1651 & 0 & 1 \\
\hline
\end{tabular}




\subsection{The Empirical Results}

This paper uses two econometric models to analyze the impact of enterprise size on GMP inspection results. OLS regression is used as the basic model. Since the inspection results can be divided to yes or no, that is, the dependent variable used in this paper is binary variable, we use Logit model as the main econometric model. In the model, enterprise characteristic variables, risk management characteristic variables, drug characteristic variables and development characteristic variables are taken as control variables and incorporated into the econometric equation.

\subsubsection{Results of OLS Model}

Table 2 is the basic model results of this paper. As can be seen from the results in the table, after controlling the enterprise characteristic variables, risk management characteristic variables, drug characteristic variables and development characteristic variables, the OLS model regression shows that the larger the number of enterprises, the better the inspection results are.

Table 2. OLS model regression results.

\begin{tabular}{|c|c|c|c|c|}
\hline Variable Name & Coef. & Std. Dev. & $\mathrm{T}$ & $\mathrm{P}>|\mathrm{T}|$ \\
\hline Special drugs & 0.1142 & 0.1112 & 1.03 & 0.3050 \\
\hline Logarithm of enterprise output value & -0.0044 & 0.0082 & -0.54 & 0.5880 \\
\hline Number of employees & $0.0009^{* *}$ & 0.0003 & 3.01 & 0.0030 \\
\hline $\begin{array}{l}\text { Enterprise Development } \\
\text { strategy for innovation }\end{array}$ & 0.0825 & 0.0563 & 1.47 & 0.1440 \\
\hline Lab maintenance cost logarithm & 0.0329 & 0.0215 & 1.53 & 0.1290 \\
\hline Number of enterprise sop & 0.0000 & 0.0000 & -0.07 & 0.9410 \\
\hline Number of serious deviations of enterprises & -0.0024 & 0.0014 & -1.7 & 0.0910 \\
\hline $\begin{array}{l}\text { Enterprises rarely encounter } \\
\text { hardware problems in implementing GMP }\end{array}$ & -0.1056 & 0.0935 & -1.13 & 0.2600 \\
\hline $\begin{array}{l}\text { Enterprises usually encounter hardware } \\
\text { problems in implementing GMP }\end{array}$ & -0.0788 & 0.0946 & -0.83 & 0.4060 \\
\hline $\begin{array}{l}\text { Enterprises often encounter } \\
\text { hardware problems in implementing GMP }\end{array}$ & -0.0300 & 0.1016 & -0.3 & 0.7680 \\
\hline $\begin{array}{l}\text { Enterprises always encounter } \\
\text { hardware problems in implementing GMP }\end{array}$ & -0.3782 & 0.2070 & -1.83 & 0.0690 \\
\hline $\begin{array}{l}\text { Enterprises rarely have } \\
\text { difficulty understanding GMP standards }\end{array}$ & 0.0995 & 0.0759 & 1.31 & 0.1910 \\
\hline $\begin{array}{l}\text { Enterprises usually have } \\
\text { difficulty understanding GMP standards }\end{array}$ & -0.0417 & 0.0835 & -0.5 & 0.6180 \\
\hline $\begin{array}{l}\text { Enterprises often have } \\
\text { difficulty understanding GMP standards }\end{array}$ & 0.0942 & 0.1025 & 0.92 & 0.3590 \\
\hline $\begin{array}{c}\text { Enterprises always have } \\
\text { difficulty understanding GMP standards }\end{array}$ & 0.1882 & 0.1761 & 1.07 & 0.2870 \\
\hline Constant term & 0.1073 & 0.1007 & 1.07 & 0.2880 \\
\hline
\end{tabular}




\subsubsection{Results of Logit Model}

Table 3 shows the Logit model regression results of influencing factors of GMP inspection. As can be seen from the results in the table, after controlling the enterprise characteristic variables, risk management characteristic variables, drug characteristic variables and development characteristic variables, we find that the larger the number of enterprises, the better the inspection results are. Companies with large number of employees are generally large pharmaceutical groups with strong strength. The production management process is controlled strictly and the production standardization is high. In addition, such enterprises have a deeper understanding of GMP and massive human resource to deal with the quality supervision of drug production, so that they can produce high-quality drugs and thus have higher competitiveness in the drug market.

Table 3. Logit model regression results.

\begin{tabular}{|c|c|c|c|c|}
\hline Variable Name & coef. & std. dev. & $\mathrm{z}$ & $\mathrm{p}>|\mathrm{z}|$ \\
\hline Special drugs & 0.6812 & 0.7380 & 0.92 & 0.3560 \\
\hline Logarithm of enterprise output value & -0.0283 & 0.0601 & -0.47 & 0.6380 \\
\hline Number of employees & $0.0068^{* *}$ & 0.0033 & 2.09 & 0.0370 \\
\hline $\begin{array}{l}\text { Enterprise Development } \\
\text { strategy for innovation }\end{array}$ & 0.6435 & 0.4180 & 1.54 & 0.1240 \\
\hline Lab maintenance cost logarithm & 0.2425 & 0.1660 & 1.46 & 0.1440 \\
\hline Number of enterprise sop & 0.0000 & 0.0003 & -0.03 & 0.9740 \\
\hline $\begin{array}{c}\text { Number of serious } \\
\text { deviations of enterprises }\end{array}$ & -0.0216 & 0.0185 & -1.17 & 0.2440 \\
\hline $\begin{array}{l}\text { Enterprises rarely encounter hardware } \\
\text { problems in implementing GMP }\end{array}$ & -0.7887 & 0.6867 & -1.15 & 0.2510 \\
\hline $\begin{array}{l}\text { Enterprises usually encounter hardware } \\
\text { problems in implementing GMP }\end{array}$ & -0.5228 & 0.6784 & -0.77 & 0.4410 \\
\hline $\begin{array}{l}\text { Enterprises often encounter hardware } \\
\text { problems in implementing GMP }\end{array}$ & -0.0946 & 0.7226 & -0.13 & 0.8960 \\
\hline $\begin{array}{l}\text { Enterprises always encounter hardware } \\
\text { problems in implementing GMP }\end{array}$ & -4.1654 & 3.4052 & -1.22 & 0.2210 \\
\hline $\begin{array}{l}\text { Enterprises rarely have difficulty } \\
\text { understanding GMP standards }\end{array}$ & 0.6866 & 0.5771 & 1.19 & 0.2340 \\
\hline $\begin{array}{l}\text { Enterprises usually have difficulty } \\
\text { understanding GMP standards }\end{array}$ & -0.5135 & 0.7113 & -0.72 & 0.4700 \\
\hline $\begin{array}{l}\text { Enterprises often have difficulty } \\
\text { understanding GMP standards }\end{array}$ & 0.5365 & 0.7659 & 0.7 & 0.4840 \\
\hline $\begin{array}{l}\text { Enterprises always have difficulty } \\
\text { understanding GMP standards }\end{array}$ & 1.0039 & 1.3086 & 0.77 & 0.4430 \\
\hline Constant term & -2.2222 & 0.7553 & -2.94 & 0.0030 \\
\hline
\end{tabular}




\section{Conclusions}

Although man, machine, material, method, environment, and measurement are a widely used analytical tool for drug production quality management, in the quality management of drug production, the most important factor, man is the first of the six elements and is the concrete executor of other links. What's more, man is also the most difficult link in the process of drug production and management. Thus, this research focuses on the factor of man.

The insufficient number of employees will inevitably lead to the insufficient quality level of drug production. According to the research results in this paper, there is a correlation between the number of employees and GMP inspection results. The smaller the number of employees, the lower the level of drug production management. This gives us the inspiration that we should first pay attention to the smaller enterprises from the perspective of supervision, increase the inspection intensity, and find the products with potential risks.

Secondly, as for enterprises, they are small in scale and lack of human resources, so they have no way to form a positive cycle and cannot effectively manage the production of drugs. After the formation of profitability, enterprises should appropriately increase the size, in order to form a favorable positive cycle. Considering the market concentration of pharmaceutical enterprises, mergers and acquisitions among pharmaceutical enterprises should be encouraged, thus, which is beneficial to make the enterprise form scale effect. Through this way, the quality management level of drug production can also be improved. At the same time, after increasing concentration of pharmaceutical enterprises, the enterprise resources can be optimized and integrated to achieve the goal of improving drug quality.

Finally, for large enterprises, due to the high standardization, the frequency of inspection should be appropriately reduced when enterprises arrange the inspection, so as to achieve the best regulatory effect. From the perspective of industry self-discipline, larger enterprises should be encouraged to participate in industry activities and publicize experience.

\section{Conflicts of Interest}

The authors declare no conflicts of interest regarding the publication of this paper.

\section{References}

[1] Barbara, G. and Immel, K. (2001) The Brief History of the GMPs for Pharmaceuticals. Pharmaceutical Technology, 7, 44-52.

[2] Drug Production Quality Management Standards (2010 Edition): Ministry of Health Order No. 79.

[3] Saraph, J.V., Benson, P.G. and Schroeder, R.G. (1989) An Instrument for Measuring the Critical Factors of Quality Management. Decision Science, 20, 810-829. https://doi.org/10.1111/j.1540-5915.1989.tb01421.x

[4] Anderson, J.C., Rungtusanatham, M. and Schroeder, R.G. (1994) A Theory of Quality Management Underlying the Deming Management Method. Academy of Man- 
agement Review, 19, 472-509. https://doi.org/10.5465/amr.1994.9412271808

[5] Kaynak, H. (2003) The Relationship between Total Quality Management Practices and Their Effects on Firm Performance. Journal of Operations Management, 21, 405-435. https://doi.org/10.1016/S0272-6963(03)00004-4

[6] Guest, D.E. (2011) Human Resource Management and Performance: Still Searching for Some Answers. Human Resource Management Journal, 21, 3-13. https://doi.org/10.1111/j.1748-8583.2010.00164.x

[7] Jiang, K.F., Lepak, D.P., Hu, J. and Baer, J.C. (2012) How Does Human Resource Management Influence Organizational Outcomes? A Meta-Analytic Investigation of Mediating Mechanisms. The Academy of Management Journal, 55, 1264-1294. https://doi.org/10.5465/amj.2011.0088

[8] Jiang, Q.Y., Gao, S.Y. and Wang, D.D. (2008) Research on Total Factor Productivity of Agricultural Product Processing Industry and Its Influencing Factors, Based on Industry Panel Data of Anhui Province. Journal of Yunnan Agricultural University (Social Science), 12, 78-83.

[9] Luo, Y.X. and Xing, H. (2018) Research on Influencing Factors of R \& D Efficiency of Pharmaceutical Enterprises in China. Family Medicine, 12, 231-232.

[10] Song, Y. and Xu, W. (2014) Enterprise Scale and R \& D Investment in Innovative SMEs. Enterprise Technology Development, 33, 20-22.

[11] ICH. Pharmaceutical Quality System Q9. Geneva: ICH.2005-11-04 [20191-14]. https://www.ich.org/fileadmin/Public_Web_Site/ICH_Products/Guidelines/Quality /Q9/Step4/Q9_Guideline.pdf

[12] ICH. Pharmaceutical Quality System Q10. Geneva: ICH.2008-06-04 [2019-1-14]. http://www.ich.org/fileadmin/Public_Web_Site/ICH_Products/Guidelines/Quality/ Q10/Step4/Q10_Guideline.pdf

[13] Data Tracking System. https://www.pharmaceuticalonline.com/doc/how-fda-and-mhra-decide-which-drug -facilities-to-inspect-and-how-often-0001

[14] Graya, J.V., Rothb, A.V. and Leibleina, M.J. (2011) Quality Risk in Offshore Manufacturing: Evidence from the Pharmaceutical Industry. 29, 737-752.

[15] Ishibashi, T., Kusama, M. and Sugiyama, Y. (2012) Analysis of Regulatory Review Times of New Drugs in Japan: Association with Characteristics of New Drug Applications, Regulatory Agency, and Pharmaceutical Companies. Journal of Clinical Pharmacy and Therapeutics, 37, 657-663. https://doi.org/10.1111/j.1365-2710.2012.01363.x

[16] Dai, J.H. and Zheng, Q. (2014) Application of Statistics Methodology in Pharmaceutical Research and Development, Manufacturing and Quality Management. Chinese Journal of New Drugs, 23, 1024-1048. 